\title{
Mining under Kalina and Selisoo Bogs
}

\author{
Merle Otsmaa \\ Tallinn University of Technology / Department of Mining \\ Address: Ehitajate tee 5, Tallinn, EE-12618, Estonia
}

\begin{abstract}
Continuous developing of Estonian power engineering on the basis of oil shale requires ever taking into use of new exploration fields. When the reserve of Estonia mine is depleted, mining of the exploration field of Seli has to be started. But that field is located under the Selisoo bog which is defined as a region of the Natura 2000 network and is planned become a nature preserve. Conservationists are interested for what extent oil shale mining under the Selisoo bog and in its immediate nearness will spoil the natural water regime of the bog. To clear up the environmental impact are carried through several investigations in the Selisoo bog. As a result of modeling is proposed a perceptible lowering of water table in peat layer.

At the same time we have a positive experience on mining under bogs and water bodies, some kilometers to the north from the Selisoo bog. In Viru mine situated under the Kalina bog there is oil shale mining practically finished for today, but the Kalina bog exists as before, also the Lake Kalina in this bog.

The aim of this research is to compare the geological and hydrogeological parameters of the Selisoo and Kalina bogs, clearing up the essential factors owing to which the mining in district of the Selisoo bog could exert a larger influence on environment than under the Kalina bog. In this paper are some measures for diminishing of the environmental impact brought on.
\end{abstract}

Keywords - underground mining, bog, water level, precipitations, water-resistance.

\section{INTRODUCTION}

Observable Selisoo bog lies in Northeastern Estonia in oil shale area beside of working Estonia mine. About $10 \mathrm{~km}$ to the north is located the lake Kalina surrounded by a bog of the same name (Fig. 1). Under that bog the reserve is depleted already. In the Estonia mine mining activities are approaching the bog Selisoo to the west. But Selisoo is defined as a region of the Natura 2000 networkError! Reference source not found. and it is planned become a nature preserve [4][4]. The aim of intended nature preserve is to protect different birds and valuable natural habitats - humus alimentary lakes and lakelets, bogs and bog forests.

Therefore all measures to prevent or reduce to a minimum changes in the natural state of Selisoo need to be carefully considered. Above all it is essential that the present water conditions will not be spoiled and biotope of that place will remain.

The reserves of Seli exploration field are validated in 01.04.1998. Only in first block the productivity is over $35 \mathrm{GJ} / \mathrm{m}^{2}$ what meets the requirements of proved resource. The area of proved reserve is 1964.20 ha. 248 ha of planned nature preserve remains above the Estonia mine.

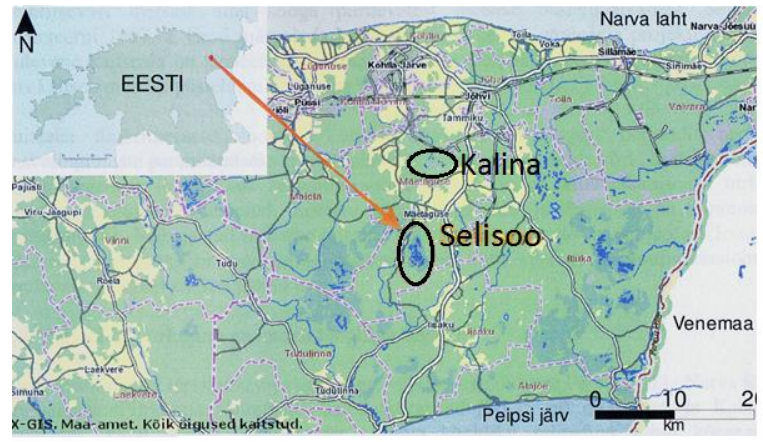

Fig. 1. Location of Kalina and Selisoo bogs [2]

\section{GEOLOGICAL CONDITIONS}

For preservation of peatlands and water bodies in mined areas is essential the good water-resistance of sediments. In table I there is presented two geological cross-sections of observation wells in comparison [6][6]. The geology of sediments is investigated also just on shore of the Lake Kalina (borehole 1 in fig. 8) [7][7], where the thickness of little-decomposed peat was measured $1.72 \mathrm{~m}$. Under peat was found $0.45 \mathrm{~m}$ of lake mud (gyttja) and $2.1 \mathrm{~m}$ clay with gravel and pebbles, containing $1-6 \mathrm{~cm}$ thick bands of sand. Sandy loam is laying in southern part of Lake Kalina, elsewhere is fine sand [7].

TABLE I

GEOLOGICAL CROSS-SECTIONS

\begin{tabular}{|l|l|l|l|l|l|}
\hline \multicolumn{2}{|l|}{ Kalina } & \multicolumn{2}{l|}{ Selisoo } \\
\hline $\begin{array}{l}85 \\
0.5 \mathrm{~km} \text { in the southeastern of the } \\
\text { lake }\end{array}$ & $\begin{array}{l}233 \\
0.8 \mathrm{~km} \text { in the western of Selisoo }\end{array}$ \\
\hline $\begin{array}{l}\text { Geol. } \\
\text { index }\end{array}$ & $\begin{array}{l}\text { Description } \\
\text { of layer }\end{array}$ & $\begin{array}{l}\text { Thick- } \\
\text { ness, } \mathrm{m}\end{array}$ & $\begin{array}{l}\text { Geol. } \\
\text { index }\end{array}$ & $\begin{array}{l}\text { Description } \\
\text { of layer }\end{array}$ & $\begin{array}{l}\text { Thick- } \\
\text { ness, } \mathrm{m}\end{array}$ \\
\hline QIV & Peat & 3 & gQIII & Sandy loam & 4.5 \\
\hline lgQIII & $\begin{array}{l}\text { Varigrained } \\
\text { sand }\end{array}$ & 1.5 & $\begin{array}{l}\text { O2- } \\
3 \mathrm{nb}\end{array}$ & $\begin{array}{l}\text { Fissured } \\
\text { dolostone }\end{array}$ & 9.6 \\
\hline $\begin{array}{l}\text { O2jh- } \\
\text { k1 }\end{array}$ & $\begin{array}{l}\text { Fissured } \\
\text { dolostone }\end{array}$ & 25 & O2rk & $\begin{array}{l}\text { Fissured } \\
\text { dolostone }\end{array}$ & 9.2 \\
\hline O2id & $\begin{array}{l}\text { Compact } \\
\text { limestone }\end{array}$ & 7.87 & O2on & $\begin{array}{l}\text { Clayey } \\
\text { limestone }\end{array}$ & 3.3 \\
\hline O2kk & Dolostone & 0.01 & O2k1 & Limestone & 8.05 \\
\hline O2kk & argilliit & 0.62 & O2jh & $\begin{array}{l}\text { Clayey } \\
\text { limestone }\end{array}$ & 10.45 \\
\hline O2kk & $\begin{array}{l}\text { Dolomitic } \\
\text { limestone }\end{array}$ & 6.86 & $\begin{array}{l}\text { O2id } \\
\text { Clayey } \\
\text { limestone }\end{array}$ & 7.9 \\
\hline O2kk & Oil shale & 5.53 & O2kk & Oil shale & 13.7 \\
\hline shale & 44.86 & Depth of oil & 53 \\
\hline
\end{tabular}


The Quaternary cover under the Selisoo bog is $1-7 \mathrm{~m}$ thick; it is the thickest in the west of the bog above the esker of Mäetaguse and the thinnest in the northern part of bog [2].

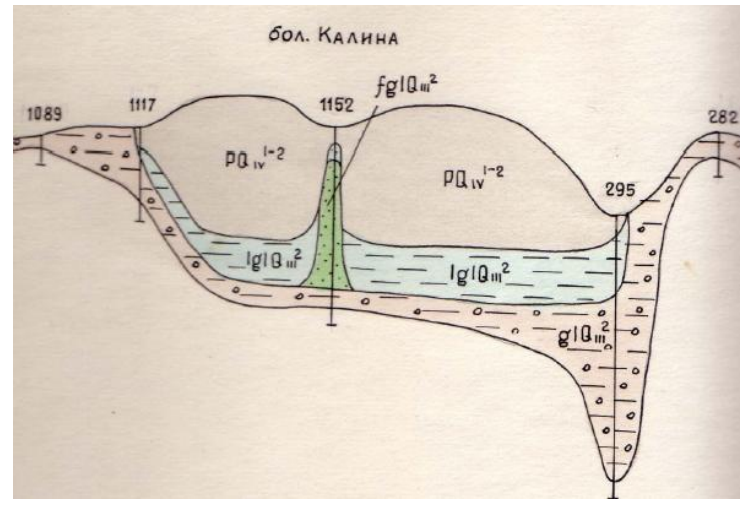

Fig. 2. Profile of Kalina bog, Quaternary deposits [13][13].

On the ground of figures 2 and 3 the both bogs are lying on a layer of silt, under what is till. Under Selisoo the silt contains $30 \%$ of pelite and $15 \%$ clay particle, which are not remarked under Kalina bog. A mound bounding the southeastern part of Selisoo is lying simply on bedrock and consists almost of pure sand, is dangerous because of large water permeability. By presence of gradient the ground water of Qaternary can move horizontally along more sandy layers in the direction of relief downfall [2].

\section{A. Jointing}

Fissured regions and crush belts are essentially facilitating the moving of water in rocks. About $5 \mathrm{~km}$ to the northeast from Selisoo is $50 \mathrm{~km}$ long and $0.5-2 \mathrm{~km}$ wide Ahtme crush belt and in the southeast $30 \mathrm{~km}$ long and $2-5 \mathrm{~km}$ wide Viivikonna crush belt [9]. The dislocation of Ahtme is about $800 \mathrm{~m}$ from Lake Kalina. The jointing belts of bedrock ranging along Mäetaguse and Metsküla eskers which width is about $150 \mathrm{~m}$ remain to the north from Selisoo [10]. In Viru mine the drainage of roof rocks has been largely influenced by an extensive karst belt ranging $420 \mathrm{~m}$ to the west of Lake Kalina along an entry on a scale of $250 \mathrm{~m} \mathrm{[12].}$

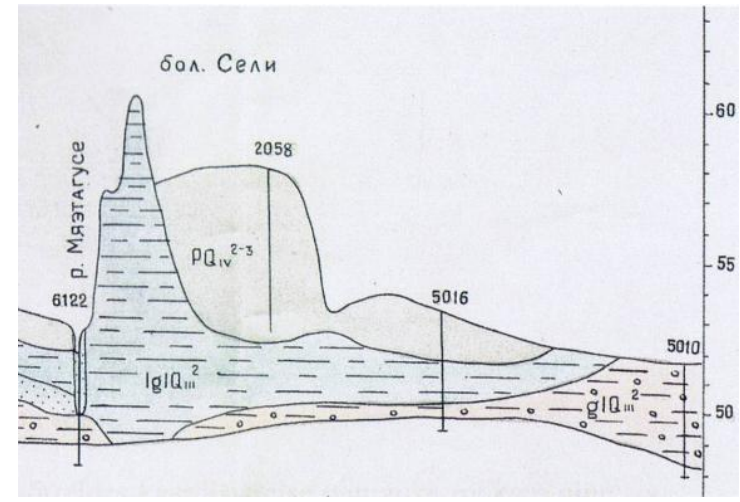

Fig. 3. Profile of Selisoo, Quaternary deposits [13].

\section{HYDROGEOLOGY}

The Ordovician aquifer system immediately under the Quaternary deposits is formed by varying layers of limestone and dolomite. As a rule their hydraulic conductivities are irregular areally and also in profile. Joint belts spreading laterally are mostly $1-2 \mathrm{~m}$ thick [30][30]. Jointing and karst decrease with depth. The filtration rate of upper $20 \mathrm{~m}$ is $10-50 \mathrm{~m} / \mathrm{d}$, in depth of 20 $-50 \mathrm{~m}$ mostly $5-8 \mathrm{~m} / \mathrm{d}$ and in depth of $50-100 \mathrm{~m}$ only $1-2 \mathrm{~m} / \mathrm{d}$ [11][8]. Water flows downwards along vertical joints. The drain from workings neighboring karst forms $20-25 \%$ of whole drain [28]. In case of rare occurrence of joints we can consider filtration rate of limestones $1 * 10^{-3} \mathrm{~m} / \mathrm{d}$.

Nabala-Rakvere aquifer is separated from KeilaKukruse aquifer by Oandu local aquitard consisting of clayey limestones and marl [14] (Fig. 4).

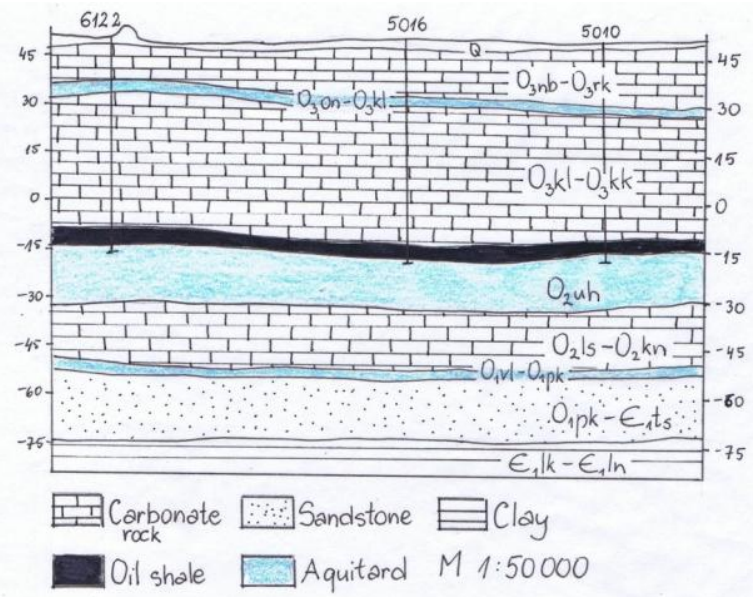

Fig. 4. Profile of Selisoo, bedrock

Nabala-Rakvere aquifer is absent under Kalina bog. There are existing Keila-Jõhvi and Idavere-Kukruse aquifers separated from each other with bands of metabentonites [15] Local aquitard in upper part of Idavere stage can consist up to 11 metabentonite bands with thickness of $1-5 \mathrm{~cm}$ [16]. Relatively waterresistant interlayers are found also in aquifers. Practice shows that in limestone above mine is water and there is possible to ground also wells [2]. It is possible, if from sides flows enough water and at the same time vertical drain is small.

\section{HYDROLOGY OF PEAT LANDS}

In mires there are natural conditions for gathering and preservation of water. Both Kalina and Selisoo bog have under peat layers a mineral bottom of concave shape what has caused formation of wetland. The water of peat deposit has free surface, its depth of bedding is $0.2-0.5 \mathrm{~m}$ from ground in natural conditions and $1.0-1.5 \mathrm{~m}$ in dewatered areas. The range of water table changes yearly $0.2-0.5 \mathrm{~m}$ [8]. Fens feed on ground water, bogs on precipitations. 


\section{B. Kalina Bog}

The area of Kalina bog is 2819 ha, from which peat extraction area covers 1239 ha [17]. Peat is produced from year 1963 to 1991 . The area of abandoned peat extraction area is 107.50 ha at present [3]. The table of surface water was in October 2006 in average $1 \mathrm{~m} \mathrm{[3]} \mathrm{in}$ drainage ditches below ground surface. In autumn 2011 the water table reached ground surface (Fig. 5).

Little-decomposed peat of abandoned peat extraction area has the medium thickness $0.9 \mathrm{~m}$ and the medium decomposition rate $17 \%$, well decomposed peat accordingly $1.0 \mathrm{~m}$ and $26 \%$ [17]. The layer of lake mud is found on 23.8 ha in surroundings of Lake Kalina. Its thickness is about $0.5 \mathrm{~m}$. Under the influence of draining in the middle part of mire the bog with stunted pines is replaced with pine bog. In places there is found hollows and treeless bog. In the northeastern part of mire water table has lowered owing to oil shale mining [8].

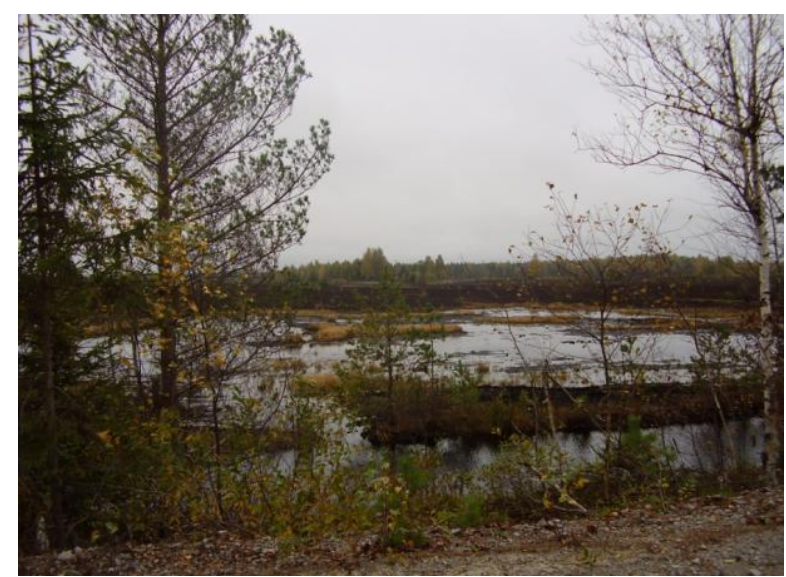

Fig. 5. Abandoned peat extraction field in Kalina bog (photo of $\mathrm{J}$. Olikainen 2011).

\section{Selisoo Bog}

The area is located on slope of Jõhvi upland what is favoring the pouring of water towards the mire. The esker of Mäetaguse bounding the mire from west and on southeastern boundary located bank are hindering the runoff of water and are very essential from the standpoint of development of mire [2].

The area of bog is 2051 ha, from what eutrophic mire covers 734 ha, mesotrophic mire 359 ha and mire 958 ha [4][24]. It is typical mire with a convex surface and very rich of bog-pools. Fen is located mostly in the northern part of the mire [8], transition bog in the eastern part.

People have influenced Selisoo by drainage ditches grounded in years 1950. - 1970. Whole mire of Selisoo is bordered with ditches and fen and transition bog are practically dewatered in the whole extent [2]. In marginal areas of Selisoo the water table is in average $1 \mathrm{~m}$ from ground surface [5].

At present, the state of Selisoo is near to the natural. Resting upon observation of this autumn wood drainage ditches are grown over with peat moss in extent of $70 \%$ and therefore the water runoff in ditches is minimal or absent at all. Also, the former small peat harvesting fields are grown over. The water table is at a depth of $0.1-$ $0.2 \mathrm{~m}$ in the whole area of abandoned peat fields what has created optimal conditions for regeneration of peat [25][25].

The maximum thickness of peat is $6.5 \mathrm{~m}$ in the mire, mesotrophical and fen peat at the outskirts is $1.0 \mathrm{~m}$ thick in average [8]. Filtration rates of peat of Selisoo are measured in two peat profiles $0.1-1 * 10^{-4} \mathrm{~m} / \mathrm{d}$ [5]. In the north and middle part there is a sporadic deposit of lake mud (gyttja) which serves as a moderate aquitard [11].

In spring the largest[8] runoff was in the northern part of Selisoo and the smallest in the western part [2]. In fall runoff from the southern part exceeded the runoff from the northern part quite essentially. We can say that discharge in southern ditches is more influenced by precipitation than in northern ditches. Northern ditches gather their water rather from forest and get supplement also from groundwater what adds the stability to dischargeError! Reference source not found.

\section{Precipitations}

The increase of amount of precipitation induces the rise of water level and herewith larger vaporization and runoff [18]. In years rich of water the surface of bog can rise 10 $-15 \mathrm{~cm}$ [19]. The arching of bog surface betters runoff and stops its further rise. By deep water level the runoff practically is absent. In the time of drought water level sinks the less the deeper it is. The preservation of bogs through the millenniums, as in the time of favorable as unfavorable climate periods give evidence of reliability of these natural systems. In case of sufficient amount of moisture peat mosses are accumulators of water consisting water over $90 \%$ of their mass. As in Estonia the amount of precipitations exceeds vaporization the mires areas would expand also nowadays. For preventing it there are digged border ditches in mires [18][18].

We have about $650-750 \mathrm{~mm}$ precipitations yearly in Estonia and $470-480 \mathrm{~mm}$ vaporization. $250-270 \mathrm{~mm}$ flows away by rivers. In clayey areas the existence of plentiful nutrient salts prevents the expanding of bogs. The best conditions for formation of bogs are in areas where on clays lying sand layer prevents and unifies runoff of water. The evaporation ability of bogs is $20-25$ mm yearly smaller than in fens.

The natural moisture content of well decomposed peat can be $500 \%$ and for weakly decomposed peat $3000 \%$ [20][20]. A rise or fall in water level of $10 \mathrm{~mm}$ is equivalent to a water gain or loss of $1 \mathrm{~mm}$ [21].

Evaporation measurements showed that the average summer daily evaporation above mire vegetation was about $1.5 \mathrm{~mm}$. It is about 3 times less than from a mineral soil with non-limiting soil moisture content [21].

In periods abounding on water a part of hollows will form to pools [18]. In waterless climate periods a part of pool have begun to grow over. The water permeability of bog was in depth of $1.5 \mathrm{~m} 10$ times and in depth of 1.03 .3 times smaller than in depth of $0.5 \mathrm{~m} \mathrm{[22][22].} \mathrm{Only} \mathrm{the}$ first $10 \mathrm{~cm}$ of peat are able to drain off big amounts of water accompanied with rainfalls. 


\section{E. Water Conductivity of Peat}

The higher is the degree of decomposition the smaller is its water conductivity. It depends also on compressibility and type of peat. In case of equal degree of decomposition the permeability of bog peats is 35 times smaller than fen peats [23]. In saturated peat difficulties between horizontal and vertical water conductivity are usually small. The results of water conductivity experiments showed that the main part of water exchange is taking place in extent of $1.5 \mathrm{~m}$ of upper part of peat.

\section{F. Mines Influence}

In natural conditions the range of yearly water level is up to $2 \mathrm{~m}$, in spoiled conditions $8 \mathrm{~m}$ and yet more [1]. Very great amount of snow melting water reaches from ground surface by means of shafts, technical bore holes and karst joints right into mine [6]. About $90-96 \%$ of mine water comes via roofs. The coefficients of storage are dependently of season $3.2-63.2 \mathrm{~m}^{3} / \mathrm{t}$ in lower northern mines and $2.6-7 \mathrm{~m}^{3} / \mathrm{t}$ in deeper southern mines [15].

In figure 6 are represented hydroisohypses of upper Nabala-Rakvere aquifer before oil shale mining. The natural water level is the highest on Ahtme uplift and lowers in the direction of Lake Peipus. In figure 7 are represented hydroisohypses of same area when Ahtme, Viru and Estonia mines were working already. The water level of Nabala-Rakvere aquifer has lowered about $10 \mathrm{~m}$, Keila-Kukruse $20-25 \mathrm{~m}$ and Lasnamä-Kunda $35 \mathrm{~m}$. During 6 years the water table has raised in closed Ahtme mine $21.5 \mathrm{~m}$.

The bale up of mine water influences above all the aquifer lying immediately on exploitation seam and the aquifer lying about $15 \mathrm{~m}$ deeper from it. In consequence of mining the pressure level of Ordovician-Cambrian water complex has also lowered about $20 \mathrm{~m}$ [14].

In the district of the Estonia mine, the radius of drawdown cone is $6-7 \mathrm{~m}$, at the same time in NabalaRakvere aquifer only $1 \mathrm{~km}$. The radius of drawdown cone in Lasnamäe-Kunda aquifer is $25 \mathrm{~km}$ [2].

Several groundwater observation wells (Fig. 9; 10) show that the water tables in Nabala-Rakvere aquifer remained stable in observing wells of Sõrumäe and Metsküla. In wells 5500 and 5504 located in the Estonia mining district the free surface of Nabala-Rakvere aquifer has lowered from year 1972 to1986 accordingly 10 and $7 \mathrm{~m}$. In wells of Kalina water table has also lowered about $10 \mathrm{~m}$.

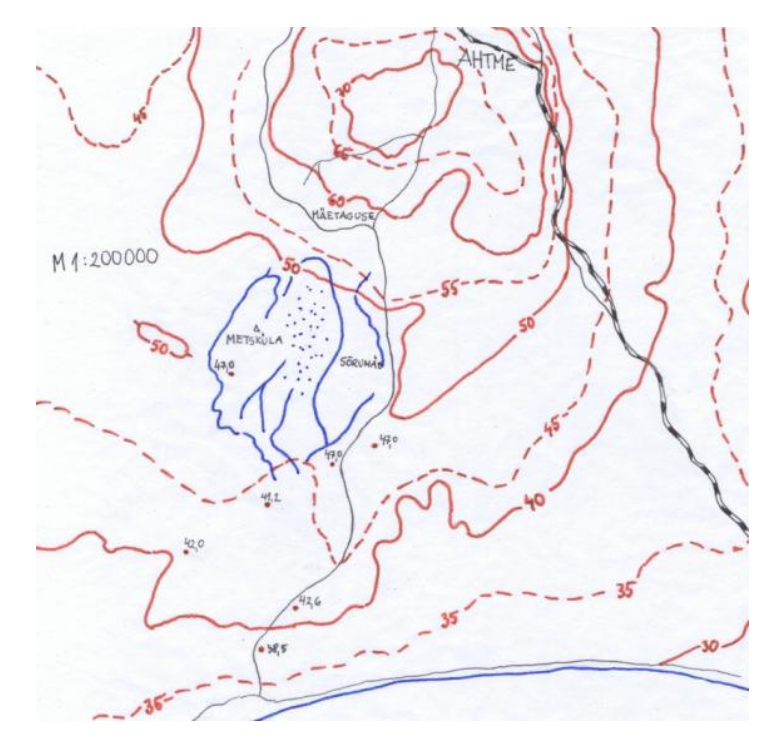

Fig. 6. The hydroisohypses of Nabala-Rakvere aquifer in 1961 [13].

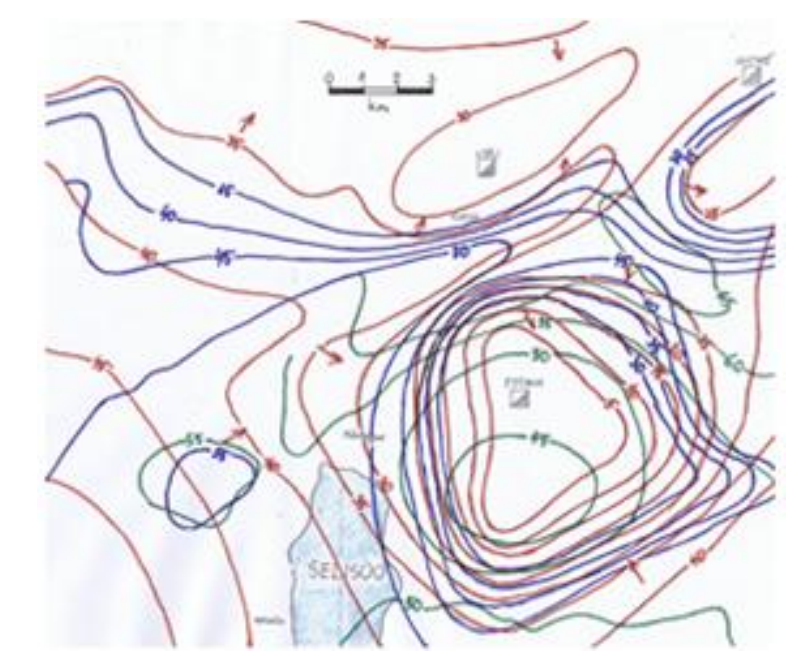

Fig. 7. Hydroisohypses in year 1987 [26]. Green line - Nabala-Rakvere aquifer, blue line - Keila-Kukruse aquifer, red line - Lasnamäe-Kunda aquifer.

\section{G. Investigations in surroundings of Lake Kalina}

Research (05.1982-04.1985 a.) ascertained that water levels in Keila-Jõhvi and Keila-Idavere aquifers were lowered in comparison with static level 10 and $20 \mathrm{~m}$ [12]. Consequently the detachment of Quaternary aquifer from bedrock's aquifer was $10-25 \mathrm{~m}$. Lake water can infiltrate to bedrock through the Quaternary deposits. Clear signs of leaking of mire or lake water into mine are heightened moisture, smell of hydrogen sulphide, heightened oxidation and content of NH4+ion, what was observed in entries opening the karst zone about a half kilometer away from the lake. Runoff was found as from horizontal as vertical joints and under the anchors. Discharges of runoff were $0.04-0.14 \mathrm{~m}^{3}$ per hour. Measuring of lake water levels since May 1982 till August 1983 showed that the volume of lake $\left(40000 \mathrm{~m}^{3}\right)$ practically didn't change. It was in 1969 the same. 
Observations began again in March-April 1995 when mining operations were approached to the lake at the distance of $70-80 \mathrm{~m}$ [7]. During 11 years water level of the lake had risen $20-30 \mathrm{~cm}$, water level of KeilaKukruse aquifer remained practically changeless and water level of Idavere-Kukruse lowered $15 \mathrm{~m}$.

In space of time $03.95-07.96$ when excavating took place directly under the lake, only seasonal fluctuations of water tables were ascertained.

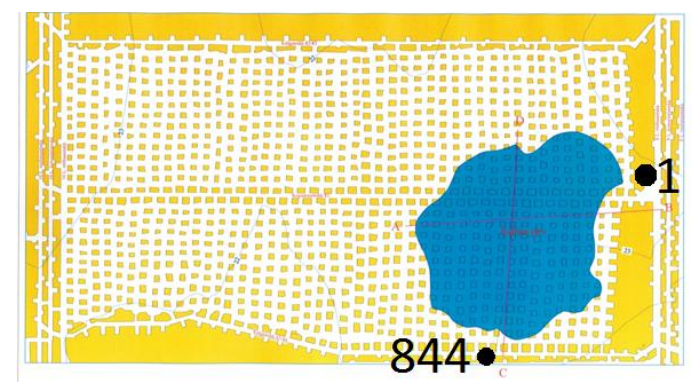

Fig. 8. Lake Kalina and the pillars in underground area.

When about a quarter of area under lake was excavated, an observation was carried through at 05.12.95 in the mine. The roof under lake was practically dry except some few moist places. Water appearance was noticed in the anomalous fissured part of an entry. From a passing energy borehole $\mathrm{nr} 844$ (Fig. 8) located $35 \mathrm{~m}$ in the southwest of the lake the water was flowing in 4 trickles with total discharge of $0.21 / \mathrm{s}$.

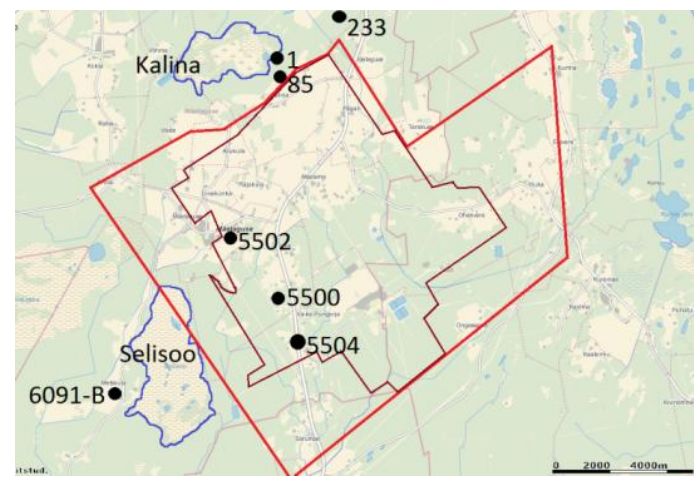

Fig. 9. The claim and depleted area of Estonia mine. Observation wells.

\section{RESULTS}

The influence of mining on mires water regime depends on horizontal and vertical water conductivity of limestone of the region. In surroundings of Selisoo upper Nabala-Rakvere aquifer ought to have been preserved by Oandu aquitard which water conductivity is very small $10^{-5} \mathrm{~m} / \mathrm{d}$ [30]. According to other data water conductivity of this aquitard is $0.0003-0.0004 \mathrm{~m} / \mathrm{d}$ [2]. Nobody has specially determined water conductivities of bedrock limestone for this research.

Existing data are very different. It is not possible to determine equable water conductivity for a layer because it varies areally and also in profile.

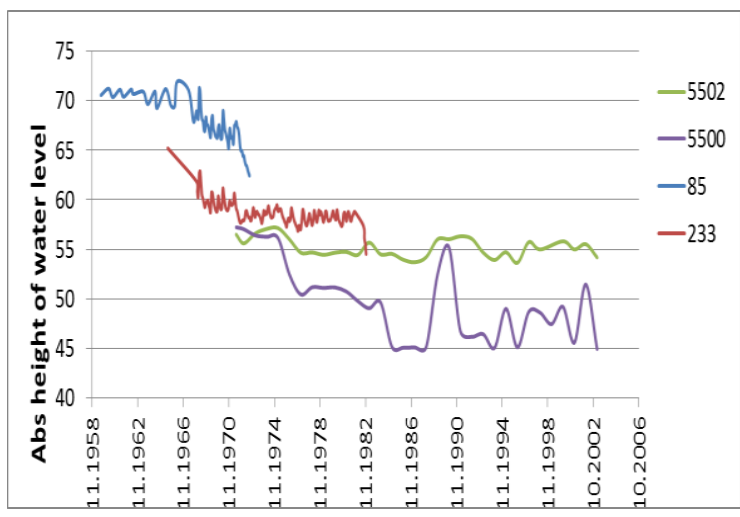

Fig. 10. Water levels in observation wells.

On the ground of data of observation wells the water table in the area of Estonia mine has lowered in upper aquifer up to $10 \mathrm{~m}$. Similarly water level has lowered also in Kalina (figure).

Quaternary sediments are also not absolutely impermeable. The medial filtration rate in Selisoo is $0.39 \mathrm{~m} / \mathrm{d}$, whereas filtration rate of silt was $1 * 10^{-3} \mathrm{~m} / \mathrm{d}$ and of sediments with higher clay containing $2 * 10^{-4} \mathrm{~m} / \mathrm{d}$ [2]. In Kalina bog the medial filtration rate of Quaternary sediments was $1.4 \mathrm{~m} / \mathrm{d}$. Medial thickness of peat was $4.5 \mathrm{~m}$ in Selisoo and only $2.5 \mathrm{~m}$ in Kalina bog. The degree of decomposition of Kalina peat is a little higher [8]. In sum we can say that these bogs are similar by their geological conditions.

In 2012 hydrogeological modeling was carried through on an area of $16 \times 27 \mathrm{~km}$ what covers Ratva bog, Selisoo and Estonia mine [5][5]. In the model there was used following filtration rates (table II). Water conductivities of carbonate rocks were partly determinated by means of fitting into working model.

TABLE II

FILTRATION RATES

\begin{tabular}{|l|l|l|l|}
\hline Layer & $\begin{array}{l}\text { Thickness, } \\
\mathrm{m}\end{array}$ & $\begin{array}{l}\text { Vertical filtration } \\
\text { rate, } \mathrm{m} / \mathrm{d}\end{array}$ & $\begin{array}{l}\text { Horizontal } \\
\text { filtration } \\
\text { rate, } \mathrm{m} / \mathrm{d}\end{array}$ \\
\hline Peat & 1 & 0.01 & 0.1 \\
\hline Peat & up to 3.4 & 0.001 & 0.03 \\
\hline Peat & up to 2.2 & 0.0002 & 0.0007 \\
\hline Mineral soil & & $0.001-0.0005$ & \\
\hline $\begin{array}{l}\text { Nabala- } \\
\text { Rakvere }\end{array}$ & 25 & 0.005 & 40 \\
\hline Oandu & $2.5-3.5$ & $0.0003-0.0004$ & $1.2-7$ \\
\hline $\begin{array}{l}\text { Keila- } \\
\text { Kukruse }\end{array}$ & 45 & 0.01 & \\
\hline
\end{tabular}

For checking the trustworthiness of the model, calculated water tables were compared with levels measured in observation wells. If the difference was below $2 \mathrm{~m}$, the result was considered good. In consequence of modeling was found out that in case of widening of Estonia mine under Selisoo water level in peat layer would lower more than $2 \mathrm{~m}$, above all in 
southern part. Therefore an aquitard of clay or peat with water conductivity not higher than $1 * 10^{-5} \mathrm{~m} / \mathrm{d}$ was considered an essential assumption. But netoinfiltration $200 \mathrm{~mm}$ yearly will also preserve the water level in conditions of maximal mining [5].

Also department of mining of TUT has made calculations about water level lowering in Selisoo [29]. On the ground of these results the water level in Selisoo would not lower during first 4 years after beginning of mining. Only the runoff by ditches will decrease. The depression cone ought to shape up within about 14 years. After this time the water table in bog has lowered by $70 \mathrm{~cm}$.

\section{CONCLUSIONS}

The investigations have shown that an absolute waterresistance in case of underground mining is not possible to gain. In Estonian oil shale area the water-resistance of Quaternary and peat deposits is more essential than waterresistance of limestone. Lake Kalina is isolated from bedrock in addition to mineral sediments with a layer of gyttja up to $0.5 \mathrm{~m}$ thick. The filtration rate is predictably in size of $1 * 10^{-5} \mathrm{~m} / \mathrm{d}$ [2]. Nevertheless nobody has determined exactly the water conductivity of that material. It is known that the layer of gyttja does not extend under the whole Kalina bog [3][17].

As regards the model there is considered the time factor not at all what makes the result quite questionable. Unfortunately whatever calculations about so large and variable geological massif are inexact. Better is to take into consideration practical experiences. Lake Kalina and the bog are preserved in spite of total underground mining (figure). Although the water level in border ditches is low, in bog there is found enough free water (Fig. 5). On the ground of investigations of year 1995 it is known that water was flowing into working $0.2 \mathrm{l} / \mathrm{s}$. It makes $6307 \mathrm{~m}^{3}$ yearly, as a result of which the lake had to be after 6 years practically empty. It is not happened owing to reliability of bogs in our climate where precipitations exceed vaporization. It is possible to increase the netoinfiltration in place of runoff.

Consequently the mining under Selisoo is possible without spoiling the water regime in bog in substance. It is needful to prevent peat water decrease by building dams before draining ditches. Water table fluctuations need to be followed and runoff in ditches measured. When building of ventilation roads and boring holes it is necessary to use only constructions isolating groundwater layers. Electricity and other communications have to be taken into mine underground. It is needful to avoid fissured and karstified zones at establishing of workings.

\section{ACKNOWLEDGMENTS}

The research is related to the grant ETF 9018 - "Mine collapses in NE Estonia - detection, identification and causes" and AR12007 Sustainable and environmentally acceptable Oil shale mining. This research was supported by European Social Fund's Doctoral Studies and
Internationalisation Programme DoRa, which is carried out by Foundation Archimedes.

\section{REFERENCES}

[1] Eesti Meteoroloogia ja Hüdroloogia Instituut. http://www.emhi.ee/index.php?ide $=6 \& \mathrm{v} \_$kiht $=6$

[2] Hang, T.; Hiiemaa, H.; Jõeleht, A.; Kalm, V.; Karro, E.; Kirt, M.; Kohv, M.; Marandi, A. 2009. Selisoo hüdrogeoloogilised uuringud kaevandamise mõju selgitamiseks. Tartu Ülikooli Ökoloogia ja Maateaduste Instituut.

[3] http://www.envir.ee/orb.aw/class=file/action=preview $/ \mathrm{id}=$ $1125327 / 6.2 .+\mathrm{II}+\mathrm{etapp}+\% 28 \mathrm{Ida}-\mathrm{Viru} \% 2 \mathrm{C}+\mathrm{L} \% \mathrm{E} 4 \% \mathrm{E} 4 \mathrm{ne}-$ Viru\%2C+J\%F5geva\%2C+J\%E4rva\%2C+Tartu+mk\%29.pdf

[4] Selisoo looduskaitseala kaitse alla võtmine ja kaitse- eeskiri. EELNÕU 22.02.2011.

[5] Gaškov, M.; Hang, T.; Hiiemaa, H.; Jõeleht, A.; Järveoja, M.; Kalm, V.; Karro, E.; Kohv, M.; Mustasaar, M.; Polikarpus, M.; Plado, J.; Rooni, K. 2012. Ratva raba hüdrogeoloogilised uuringud ja Selisoo seiresüsteemi rajamine. Tartu Ülikooli Ökoloogia ja Maateaduste Instituut

[6] http://loodus.keskkonnainfo.ee/WebEelis/veka.aspx?type= artikkel\&id=214457803

[7] Доманова, H. 1996. Оценка влияния горных работ шахты Виру на уровень воды озера Калина. Jõhvi. AS Eesti Põlevkivi Rakendusuuringute Keskus.

[8] Orru, M., Allikvee, H. „Kohtla-Järve rajooni turbamaardlate otsingulis-uuringuliste tööde aruanne.“ Keila, EGF 5162, 1975.

[9] Puura, V.; Vaher, R. Cover structure. In: A. Raukas and A. Teedumäe (eds.) Geology and mineral resources of Estonia. Tallinn, $167-176$

[10] Heinsalu, Ü. Andra, H. 1975. Lõhelisus Eesti põlevkivirajoonis ja selle geofüüsikalised uurimismeetodid. Tallinn, 47 - 62.(vene keeles)

[11] Perens, R., Vallner, L. Water-bearing formation. 1997.

[12] Toomik, A.; Domanova, N.; Lužetski, A. 1985. Kokkuvõte Viru kaevanduse mõjust Kalina järvele. Jõhvi. AS Eesti Põlevkivi Rakendusuuringute Keskus.(vene keeles)

[13] Tassa, V.; Erisalu, E. 1967 Aruanne Komplekssest geoloogilishüdrogeoloogilisest kaardistamisest mõõtkavas 1:50 000Eesti põlevkivimaardla keskosas 1965.-1967.a. EGF 2924. (vene keeles).

[14] Savitski, L. „Hüdrogeoloogilised tingimused.“ Rmt: Kattai, V., Saadre, T., Savitski, L. „Eesti põlevkivi: geoloogia, ressurss, kaevandamistingimused“, 2000.

[15] Domanova, N. 1986 Ajutised metoodilised soovitused kaevandusvee moodustumise uurimiseks ja prognoosimiseks Eesti põlevkivimaardlas. Skotšinski-nim. Instituut, Eesti filiaal. Moskva. (vene keeles)

[16] Pirrus, E. 2001 Eesti geoloogia.

[17] Klimenko, V.; Võsa, A. 1992 Puhatu, Tudulinna, Hiiesoo ja Peeri turbamaardla tootmisalade järeluuring Ida-Virumaal. EGF 5272.

[18] Valk, U. 1988 Eesti sood.

[19] Arefjeva, A. 1963 Sfagnumisoode pinna sesoonsed kõikumised hüdrometeroloogiliste faktorite mõjul. Riikliku Hüdroloogiainstituudi tööd. Leningrad. (vene keeles).

[20] Wong, L. S.; Hashim, R.; Ali, F. H. 2009 A Review on Hydraulic Conductivity and Compressibility of Peat. Journal of Applied Sciences 9, ISSN 1812-5654.

[21] Maggs, G. R. 1997 Hydrology of the Kopouatai Peat Dome. Journal of Hydrology (NZ) 36(2): 147-172.

[22] Holden, J., Burt, T. P. 2003 Hydraulic conductivity in upland blanket peat: measurement and variability. Hydraulical Processes, $17,6,1227-1237$.

[23] Kostjakov, A. 1951 Maaparanduse alused. Moskva (vene keeles).

[24] Arold, I. „Eesti maastikud“. TÜ Kirjastus, 2005.

[25] Orru, M. „Dependence of Estonian Peat Deposit Properties on Landscape Types and Feeding Conditions". Tallinn, 2010

[26] Saadre, T., Stumbur, H., Martin, T., Mardim, T., Luht, H., Jürjens, E., Kala, E., Suuroja, K. "Eesti põlevkivimaardla varasema uuringu järeluuring M 1:50000 1985. - 1989.a. "EGF 4311 (vene keeles), 1989. 
Otsmaa M. MINING UNDER KALINA AND SELISOO BOGS

[27] Savitski, L. Savva, V. 2005 Teostatavusuuringu läbiviimine ja äravoolu põhiskeemi koostamine sade-, pinna-, drenaaži- ja kaevandusvete ärajuhtimiseks Kohtla-Järve ja Jõhvi piirkonna tiheasustus- ja tootmisaladelt. 5.5. Veebilansside koostamine valgaladel. Kaevandusvee bilanss. EGF 7671.
[28] Gazizov, M. 1971 Karst ja tema mõju mäetöödele. Skotšinski-nim. Instituut. Moskva. (vene keeles)

[29] Otsmaa, M. 2012. Water Balance of the Selisoo Bog and its Changes Caused by Underground Mining.

[30] Vallner, L., Jõgar, P. 1980 „Eesti hüdrogeoloogia probleemid.“ 